\title{
Early Childhood Education Teacher's Readiness of Computer Literacy for Facing The 4.0 Industrial Revolution
}

\author{
Avanti Vera Risti Pramudyani ${ }^{1}$, Toni Kus Indratno ${ }^{2}$, Prima Suci Rohmadheny ${ }^{3}$ \\ PGPAUD, Fakultas Keguruan dan IImu Pendidikan, Universitas Ahmad Dahlan ${ }^{13}$ \\ Pendidikan Fisika, Fakultas Keguruan dan IImu Pendidikan, Universitas Ahmad Dahlan² \\ avanti.pramudyani@pgpaud.uad.ac.id ${ }^{1}$
}

Info Artikel

Submitted: 06 October 2019

Accepted: 07 November 2019

Published: 09 November 2019

DOI: 10.26555/jecce.v2i2.1150

Copyright (C) 2019 Universitas

Ahmad Dahlan

\section{Abstrak}

Menghadapi revolusi industri 4.0 bagi dunia pendidikan dilakukan dengan menyiapkan sumber daya manusia yang memiliki keterampilan berpikir kritis dan pemecah masalah, keterampilan komunikasi dan kolaboratif, berpikir kreatif dan inovatif, serta mengusai literasi teknologi informasi dan komunikasi. Tujuan dari penelitian ini adalah mengetahui sejauh mana guru PAUD dalam pengusaan computer literacy berdasarkan tugas dan tanggung jawabnya sebagai pendidik dalam proses pembelajaran. Penelitian ini adalah penelitian pendekatan mix method (kuantitatif dan kualitatif) dengan instrumen pengumpulan data berupa kuesioner dan wawancara. Analisis data yang digunakan adalah analisis deskriptif deduksi, yaitu menganalisis dan memberikan interpretasi terhadap data yang terkumpul. Subjek penelitian ini melibatkan 58 guru bersertifikasi profesional dan pernah mengikuti pelatihan dengan topik TIK. Hasil penelitian menunjukkan bahwa tingkat kesiapan guru dalam computer literacy baru pada kesiapan faktor pendukung yaitu memiliki laptop dan pengusaan keterampilan aplikasi dasar berupa Ms. Office (words, ppt, excel) dan mesin pencari hanya untuk menunjang pekerjaan dalam kegiatan menyusun administrasi pembelajaran.

Kata Kunci : kesiapan guru, melek komputer, revolusi industri

\begin{abstract}
Facing the 4.0 Industrial Revolution in education is done by preparing human resources that have critical thinking skills and problem solvers, communication and collaborative skills, creativity and innovative thinking, and literacy of Information and communication technology. This research aims to know the extent of teachers at ECE in the of computer literacy based on their duties and responsibilities as educators in the learning process. This research is using the mixing method (quantitative and qualitative) approach with data collection instruments in the form of questionnaires and interviews. Analysis of the data used is a descriptive analysis deduction, namely analyzing and providing an interpretation of the collected data than needed studies. The subject of this study involved 58 professional certified teachers and had participated in training on ICT topics. The results showed that the level of readiness of teachers in the computer literacy on the readiness of supporting factors is to have a laptop and the basic skills of the applications in the form of MS office (words, PPT, Excel) and search engines only to support they working in organizing the learning administration.
\end{abstract}

Keywords : teacher readiness, computer literacy, revolution industry 


\section{INTRODUCTION}

The fourth industrial revolution is one of the steps of technology advancement began since 2000s. One of the most fundamental transformations in this revolution is the usage of digital technology and the internet in all human activities, from industry until the education sector. As it is stated by (Merkel, 2014) in OECD Conference, an industrial transformation can be seen through the combination of digital technology and the internet and the conventional industry. For educational sector, its impact emphasizes more on preparing human resources with technology mastery.

Human resources needed in the industrial revolution 4.0, particularly in educational sector, are those possessing critical thinking and problem-solving skills, communication and collaborative skills, creative and innovative thinking, and information, communication and technology mastery. (Darmawan, 2018). Teachers, as the spearhead of an educational process, should develop those skills to prepare students for facing industrial revolution 4.0. Before preparing their students, the first step a teacher can take is mastering the required skills for this purpose.

Out of four skills mentioned earlier, mastering information, communication and technology is the priority. This is supported by (Astini, 2019) who states that having ICT mastery is helpful for teacher not only to meet their professional requirements but also to help them during learning processes. Teacher's ICT mastery has different scopes from other professions has, teacher's mastery emphasizes more on utilization during the learning process.

Besides helping the learning process and complying with professional requirements, a teacher with IT mastery is considered to have computer literacy. According to (Sturges \& Gastinger, 2010), computer literacy refers to skills in using computer software such as word, database, and spreadsheet, application, and supporting devices such as printer and scanner. The purpose of computer literacy is the skills to use and operate computers efficiently.

For teachers, it is not necessary to see computer literacy as advanced software mastery. Instead, they need to focus more on skills to use computer to ease their works. A study conducted by (Astini, 2019) found that the form of Elementary school teacher's computer literacy involves skills to use computer, LCD, internet, learning CD, e-mail, PPT, and multimedia. For Early Childhood Education (ECE) teachers, computer literacy is something challenging. Based on the result of preliminary study, we found a number of obstacles faced by ECE teachers such as low level of IT knowledge and skills compared to teachers in different education level (Elementary School, Junior High School, and so forth), the administrative system that does not require computer use, and lack of IT use in learning process.

Surprisingly, teachers who have computer mastery certificate is found to have low level of computer literacy, too. These teachers use their skills only when making lesson plans and few other activities requiring computer use. Accordingly, there are some shortages when using a computer as a learning media (Malakauskienè \& Šaparnienè, 2007).

ECE teachers' low computer literacy does not only affect their professionalism and readiness in facing industrial revolution. According to (Muthamainnah, 2016), teacher's computer literacy represents their pedagogical competence in properly integrating education technology in learning. The better the teacher's readiness in utilizing IT, the better the learning process. That study found that teacher's low computer literacy is caused by their unreadiness.

The present study aimed to find out the level of teacher readiness regarding computer literacy, especially basic computer application, as one of the attempts in facing the industrial revolution. The result of the study is expected to be the basis for developing training programs, particularly for ECE teachers, to master IT in the learning process. The present study can be used as a collaborative example between IT 
utilization and the early childhood education learning process. Besides, the result of the study can be a breakthrough for ECE teachers to use IT in learning activities, especially during administrative processes.

\section{METHOD}

The present study was categorized into the Sequential Quan-QUAL mixed method design (Tashakkori \& Teddlie, 2010). The study was begun by quantitative study through a survey using a questionnaire. It aimed to gain a depiction of software the teachers frequently use when carrying out their duties. The survey result was then analyzed using qualitative approach, this phase aims to obtain a more in-depth description, which is strengthened through interviews. The outline of the study is shown in the following figure 1 :

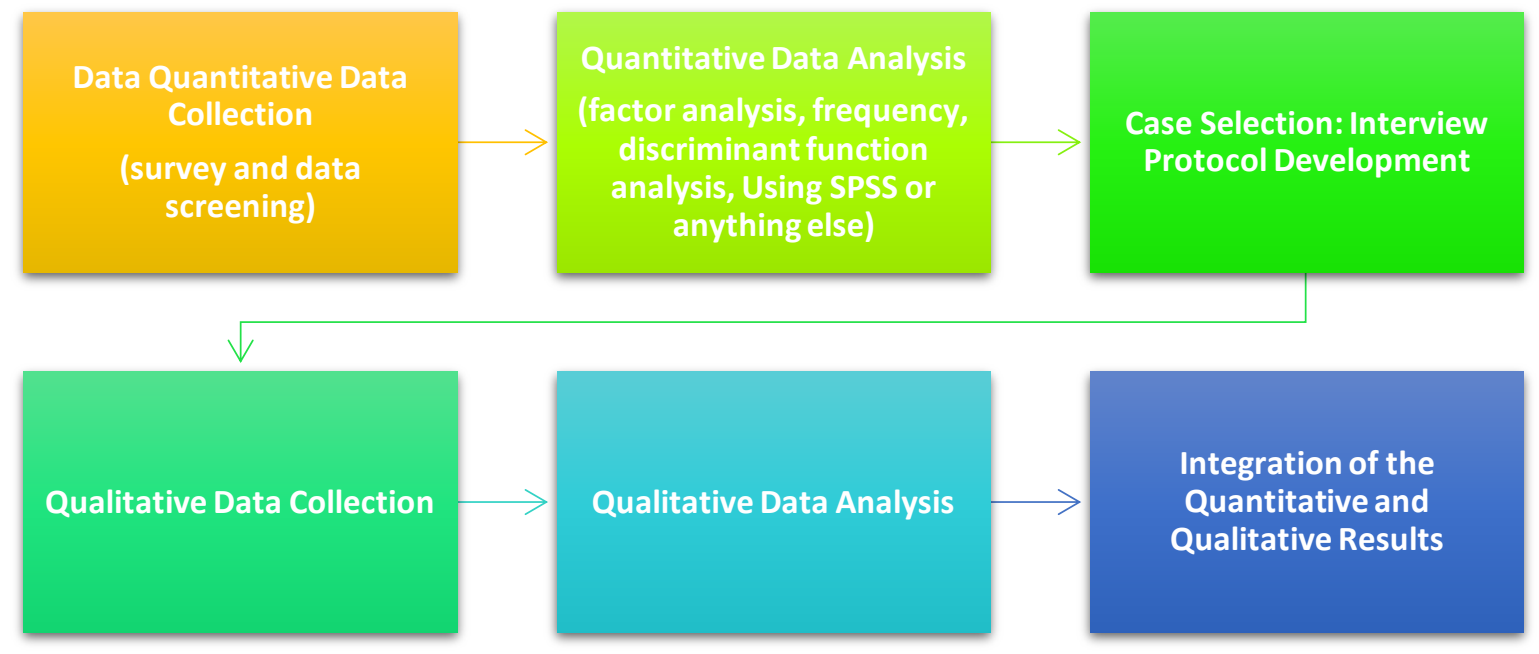

Figure 1. Sequential Quan-QUAL Mixed Method Research Procedure

The subjects of the study were ECE Institution in Special Region of Yogyakarta, Central Java, East Java, West Java, and Jakarta. The samples were selected using purposive sampling. The selected samples were fifty-eight teachers who had participated in IT training and had professional teacher certificate.

The result of descriptive analysis is then deductively analyzed by classifying the general facts into more specific field, resulting in more specific reconstruction.

\section{RESULT AND DISCUSSION}

\section{Result of the Study}

The data were collected using questionnaires made with Google form. There were twenty-five questions the teacher should answer by selecting a scale of 1 to 5 . Unstructured interview was conducted with ECE teachers. The following figure 2 is the form for collecting data related to teacher's readiness in facing industrial revolution 4.0. 

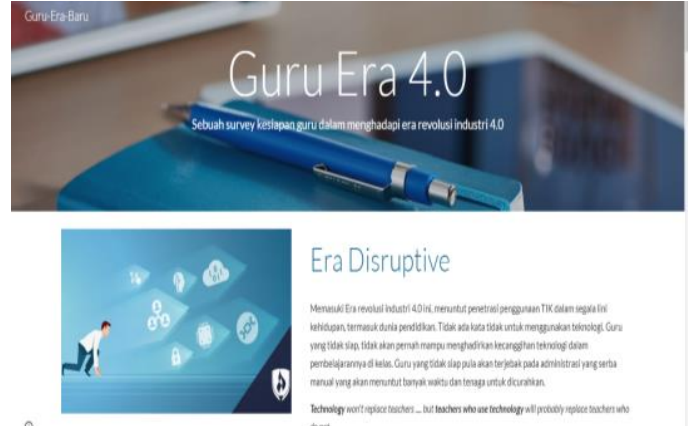

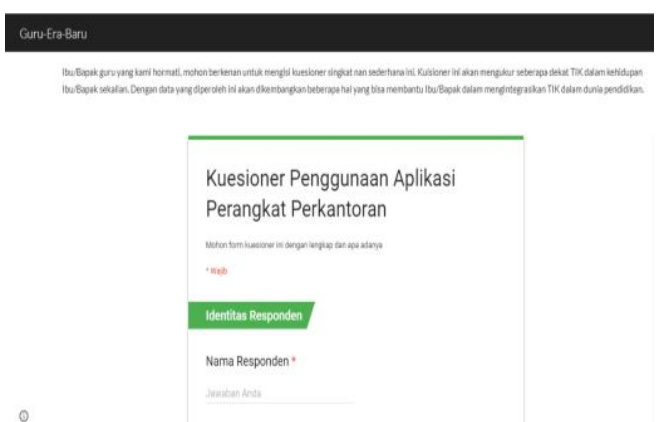

Figure 2. Questionnaire

The survey obtained the data regarding the use of hardware (laptop and printer) for learning activities in ECE. The following is the depiction of laptop use in one day, $26 \%$ of them used it for 2-3 hours, $33 \%$ of them used it for $3-4$ hours, $19 \%$ of them used it for $4-5$ hours, and $22 \%$ of them used it for more than 5 hours. All respondents stated that they used laptop only for working on learning administration such as designing RPPH and assessment instruments. For respondents who were appointed as school principals and members of the curriculum team, they used their laptop not only for designing RPPH but also for designing Annual Plan, Semester Plan, and other school administration such as invitation letter. The following figure 3 depicts the use of laptops.

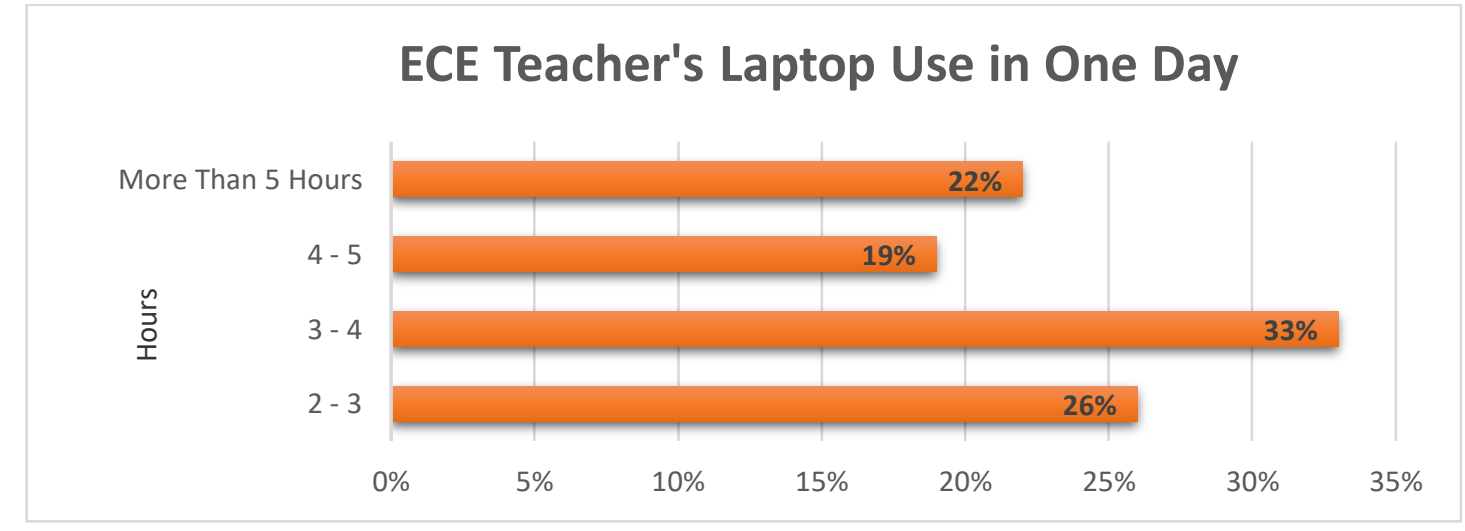

Figure 3. ECE Teacher's laptop use in one day

The respondents also state about applications they use in their daily life, especially basic applications like Microsoft Office. The followings are the percentage of software utilization: $24 \% \mathrm{~ms}$ words, $22 \%$ ms excel, $20 \%$ ms ppt, $13 \%$ media player, and $21 \%$ search engines such as Google, Mozilla Firefox, or internet explorer. The following figure 4 shows the ECE teacher's basic application uses. 


\section{ECE TEACHER'S BASIC APPLICATION USE}

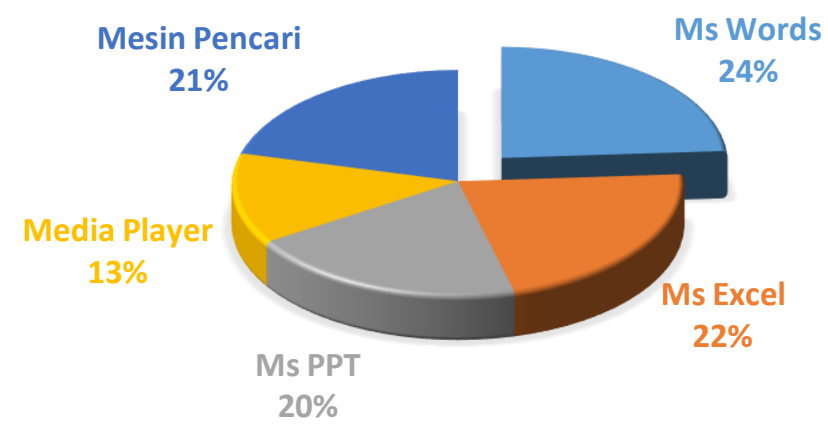

Figure 4. ECE teacher's basic application use

The respondents state that $51 . \%$ of them use ms.office for $2-3$ hours, $7.4 \%$ of them use it for $3-4$ and $4-5$ hours, and $33.3 \%$ of them use it for more than five hours. They use the applications only for doing their work as teacher. All respondents stated that they utilize Microsoft word to finish their work. $81 \%$ of them also utilize Microsoft Powerpoint, while $19 \%$ of them never use Ms. Power point. Regarding the use of Microsoft Excel, $88 \%$ of the respondents use it for work, while the rest $12 \%$ of them never use it. The following table 1 shows the use of Microsoft office among the ECE teacher:

Table 1. ECE Teacher's Basic Application Use (Duration and it's Purpose)

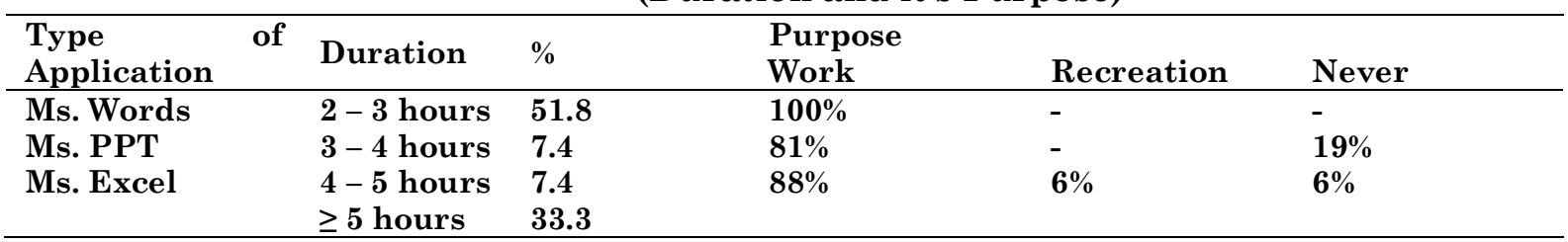

For utilizing search engines, $74 \%$ of respondents spend $2-3$ hours per day, $14.8 \%$ of them spend $3-4$ hours per day, $3.7 \%$ of them spend $4-5$ hours per day, and $7.4 \%$ of them spend more than 5 hours. $74 \%$ of the respondents state that they used search engines for work purposes, $15 \%$ of them used it for reading news, $4 \%$ of them used it just for fun, and $7 \%$ of them never used search engines. The following table 2 shows ECE Teacher's use of search engine and its duration.

Table 2. ECE Teacher's Search Engine Use

(Duration and its Purpose)

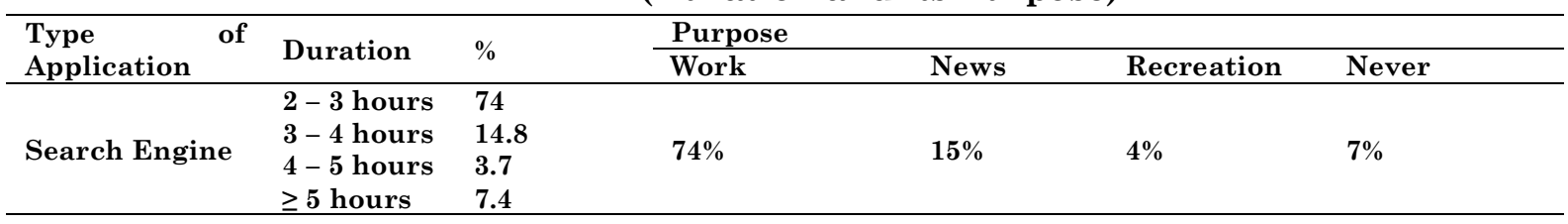

All respondents have utilized basic application everyday, they used it, the duration was 2-3 hours per day, both for Ms. Office and search engine use. Regarding the ease of use, All respondents stated that Ms. Word and search engines are the easiest, $85 \%$ of the respondents consider ms.excel as the secondeasiest, while $81 \%$ of them consider ms.ppt as the third easiest application.

\section{Discussion}

For the respondents, computer literacy covers laptop and printer use, and software use such as ms.office, and search engine. According to (Nasution, 2013) computer literacy involves all skills, attitudes, and knowledge required to understand and to operate IT basic function that consists of hardware such as 
PC, laptop, cellphone, and software. It is supported by (Sturges \& Gastinger, 2010), who state that computer literacy emphasizes more on the skill to use and operate computer as information-processing machine. Based on the statements above, it can be said that the ECE teacher has mastered the most basic stage of computer literacy, namely, the use of ms. Office and search engine.

Although the ECE teacher exhibit computer literacy in utilizing basic application, some of the skills still needs improvements. Based on the result of the study, it is concluded that the teacher utilizes the application to work on learning administration, namely Annual Planning, Semester Plan, RPPM, RPPH, assessment sheet, and creating invitation letter. According to the findings from (Astini, 2019), computer literacy refers to skills in utilizing technology to do research, set, evaluate, communicate, and to understand the rule of IT use. By implementing them, a teacher can be considered having computer literacy.

It is in line with (Merkel, 2014) in his statement regarding the characteristic of industrial revolution that involves internet and technology in conventional activities. Conventional activities in learning process performed by the teacher are not merely learning administration. A professional teacher even has various additional task such as conducting Classroom Action Research and write it for publication. Such activity was once conducted conventionally, now it should involve technology. Nevertheless, based on the study result revealed that teachers utilize technology and the internet merely for administering learning activities or other learning instruments.

ECE teacher's Sub-optimal mastery related to computer literacy is caused by their unreadiness, among others. This is in line with (Septina \& Akbariansyah, 2019) who found that the human resources (teacher) do not have enough quality in terms of personal and personal competence to cope with industrial revolution 4.0 challenges. It is supported by the finding of the study conducted by (Nurhayati, 2016), it was found that there were some hindrances faced by teachers in mastering IT, such as low IT basic skill, insufficient facility, absence of rule or policy to apply IT during learning process, time limit to prepare IT-based media, teacher's perception that the book is enough for learning sources, teacher's comfort with conventional methods, and there has been no IT training.

ECE teacher's low level of IT knowledge and skill is not a new issue. Such a shortage may be caused by physical factor, and it is understandable, however it is not only caused by physical shortage. This is supported by the finding from (Dincer, 2016), it was found that the student's computer literacy level is basic. Besides, computer literacy is not only associated with cognitive skills but also psychomotor skills; accordingly, the assessment should cover these two aspects. Based on the statement, it could be concluded that mastering computer literacy may develop various aspects within an individual. Accordingly, it is important for professionals to have it.

Following the study conducted by (Aitokhuehi, Oseghale, \& Ojogho, 2014), female high school students in Nigeria show better performance in computer literacy than the male students do. However, they still emerge as problems since both works require skills to obtain computer literacy. Computer literacy is important not only for professionals but also for learners because computer literacy cannot be separated from human life.

The problems stated by (Nurhayati, 2016), (Dincer, 2016), and (Aitokhuehi, Oseghale, \& Ojogho, 2014) are similar to those faced by the respondents of the present study. The respondents have low level of IT-related skills. The teachers are not used to utilize internet and technology in learning process, accordingly their learning process only has minimum IT utilization. Such a condition indicates ECE teacher's unreadiness in facing industrial revolution challenge. According to (Djamarah, 2002), readiness is affected by three factors, physical, psychological, and supporting materials factors. With regard to physical 
factors, physical readiness is associated with health, which affects the outcome. In other words, unhealthy teacher does not have physical energy or power to learn or to do something. Regarding psychological factors, they are associated with intelligence, good memory, satisfaction, motivation, concentration, and attention. Supporting materials are associated with the facilities used for learning.

According to (Djamarah, 2002), physically, the respondents were certified, professional kindergarten teacher whose age is no longer young. On average, certified ECE teachers are older than 40 years old, meaning that their health performance is not as good as the younger teachers. Regarding psychological factors, we cannot discuss more on satisfaction, motivation, concentration, or attention. However, regarding intelligence, the result of the study concludes that the teacher's low level of knowledge and skill indicates a shortage of psychological factors. The last factor is material availability. With regard to this matter, the teachers do have laptop to support the learning process, however, the usage frequency is still very low, only 2-3 hours per day. Although the teachers have participated in IT training, they have not implemented the training outcome massively.

Thus, it could be concluded that the teachers have not satisfied all factors. Regarding readiness, these three factors are associated with one another. For instance, in order to do an activity involving procurement of materials to learn, it is necessary to have a good health and organized supporting devices (Djamarah, 2002). In other words, readiness refers to a condition when an individual is ready to learn and prepare stimulus or responses in the learning process. Accordingly, teachers can be considered not ready to face industrial revolution 4.0.

Teachers with IT mastery will not only be able to face industrial revolution 4.0 but also possess improvement of learning activities, such as method and learning outcome changes. It is supported by (Hermanto, Marsudi, Subali, \& Hendrajati, 2018) stating that teachers with IT skills and knowledge can design more interesting learning method, more varied learning sources, which encourages students to participate in learning activity, improve their achievement, and eventually result in higher number of enrolling student. This finding is also supported by (Anderson, 1983), the finding shows that technology advancement is inevitable, if computer mastery is integrated with Curriculum in Elementary school and Junior High School, then the teacher should receive computer training beforehand.

By mastering IT, the teacher and the school would find it easier to implement Curriculum 2013 as a part of policy changes. By the implementation of Curriculum 2013, teachers have more administrative tasks in addition to teaching as their main duty. (Imam, 2015)Found that IT utilization in designing lesson plan is positively associated with the implementation and evaluation of Curriculum 2013.

The limitation of the study lies in the perspective of viewing readiness merely as ECE teacher's skill and knowledge of computer literacy as a characteristic of industrial revolution 4.0. Another factor supporting readiness, such as satisfaction, motivation, concentration, or attention, has not been completely discovered.

\section{CONCLUSION}

The industrial revolution is a challenge that should be faced by all sectors, including the education sector as the provider of human resources. In order to face the challenges, human resources should be prepared by having computer literacy. Learning activity, as human resource preparation process, requires teacher to have computer literacy as a role model for the students.

Based on the result of the study, it was found that the teacher's computer literacy is at the most basic level, namely, the utilization of basic applications such as ms. Office and search engines only to 
support their work. Teacher's computer literacy covers optimal IT utilization to do research, to set, to evaluate, to communicate, and to understand the IT rules.

This Sub-optimal utilization is caused by the teacher's lack of readiness in facing industrial revolution 4.0 challenges. Teacher's readiness covers only supporting material, i.e., having a laptop to support the work.

\section{REFERENCES}

Aitokhuehi, Oseghale, J., \& Ojogho, J. (2014, September). The Impact of Computer Literacy on Students' Academic Performance in Senior Secondary. Jurnal of Educational and Human Development, 3(3), 265 - 270. doi:10.15640/jehd.v3n3a21

Anderson, C. A. (1983). Computer Literacy: Changes for Teacher Education. Jurnal of Teacher Education, 6 9.

Astini, N. S. (2019). Pentingnya Literasi Teknologi Informasi dan Komunkasi Bagi Guru SD Untuk Menyiapkan Generasi Milenial. Seminar Nasional Dharma Arcaya Ke 1. Tantangan dan Peluang Dunia Pendidikan di Era 4.0 (pp. 113 - 120). Singaraja, Bali: STAHN Mpu Kuturan Singaraja.

Darmawan, J. (2018, November 28). https://aceh.tribunnews.com. Retrieved from www.serambinews.com: $\quad$ https://aceh.tribunnews.com/2018/11/27/menjadi-guru-erapendidikan-40.

Dincer, S. (2016). Assesing Computer Literacy of University Graduates. The Third International Conference on Open and Flexxible Education (pp. 294 - 303). Hongkong: The Open University of Hongkong.

Djamarah, S. (2002). Rahasia Sukses Belajar. Jakarta: Rineka Cipta.

Hermanto, Marsudi, Subali, E., \& Hendrajati, E. (2018). Efektivitas TIK untuk Peningkatan Proses Belajar Mengajar di PAUD, TK dan Madrasah Diniyah "Mamba'ul Hisan Dusun Sekargadung, Desa Balerejo II, Kecamatan Panggungrejo, Kabupaten Blitar. SEMATEKSOS 3 "Strategi Pembangunan Nasional Menghadapu Revolusi Industri 4.0 (pp. 77 - 84). Surabaya: ITS.

Imam, F. N. (2015). Pemanfaatan TIK pada Pembelajaran Oleh Guru SMP Negeri 1 Ungaran Dalam Rangka Implementasi K13. Skripsi tidak diterbitkan. Semarang: Universitas Negeri Semarang.

Malakauskienè, L., \& Šaparnienè, D. (2007). Computer Literacy in the Context of School as a Learning Organization. Social Research / Socialiniai tyrimai, 73 - 85.

Merkel, A. (2014, Februari 19). https://www.bundesregierung.de. Retrieved Oktober 03, 2019, from https://www.bundesregierung.de/breg-en/chancellor: https://www.bundesregierung.de/bregen/chancellor/speech-by-federal-chancellor-angela-merkel-to-the-oecd-conference-477432

Muthamainnah, I. (2016). Kesiapan Guru Kelas Menggunakan Media Teknologi Informasi dan Komunikasi (TIK) dalam Pembelajaran di Jakarta Selatan. Skripsi tidak diterbitkan. Jakarta: UIN Syarif Hidayatullah Jakarta.

Nasution, L. H. (2013). Analisis Literasi Informasi Pengguna Perpustakaan Universitas Sumatra Utara. Tesis tidak diterbitkan. Bogor: Institut Pertanian Bogor.

Nurhayati, T. (2016). Problematika Guru dalam Menguasai TIK Pada Pembelajaran Pendidikan Agama Islam dan Solusinya di MI Al-Asy'ari Kuniran, Batangan Kabupaten Pati. Skripsi tidak diterbitkan. Semarang: Universitas Negeri Walisongo.

Septina, R., \& Akbariansyah. (2019). Meningkatkan Profesionalisme Guru Dalam Menghadapi Tantangan Global di Era Revolusi Industri 4.0. Seminar Nasional Pendidikan (pp. 713 - 724). Palembang: Pasca Sarjana Universitas PGRI Palembang. 
Sturges, P., \& Gastinger, A. (2010). Information Literacy as Human Right. Libri, 195-202. Retrieved from https://www.researchgate.net:

https://www.researchgate.net/publication/259672528_Information_Literacy_as_a_Human_Righ t.

Tashakkori, A., \& Teddlie, C. (2010). Mixed Methodology. Mengombinasikan Pendeketan Kualitatif dan Kuantitatif. (B. P. Priadi, Trans.) California: Sage Publication. 